\title{
Saharan Migrant Shepherds: Znāga Social Status and the Global Age
}

\author{
FRANCISCO FREIRE \\ Rua da Rosa, 287, 2º 1200-385 Lisbon, Portugal; \\ Post-doctoral researcher at CRIA, Faculdade de Ciências Sociais e Humanas, \\ Universidade Nova de Lisboa \\ francisco.s.freire@gmail.com
}

\begin{abstract}
In the late twentieth century 300 Mauritanian shepherds travelled to the United Arab Emirates in order to tend the herds of some of this country's most prominent leaders. These low-tech subjects of global migration flows were particularly valued and sought after by their Emirati employers for their expertise in raising camels. I will here present some of the agents involved in this transit, focusing on the reintegration of these shepherds in Mauritanian stratified tribal spheres, following their widespread return to the Sahara. The possibility of a statutory reconversion (after a financially rewarding experience in the Gulf) will be central to the discussions essayed in this article, given the pervasive designation of these shepherds as a 'tributary' (znāga) group, through the application of the tripartite model which, to a large extent, still defines Mauritania's arabophone population.
\end{abstract}

Keywords: Shepherds, Mauritania, south-western Sahara, social status, tribe (qabīla), emigration, globalisation, United Arab Emirates.

\section{INTRODUCTION}

The prominence and academic prestige of studies devoted to African pastoral societies is now lost in a handful of exotic textbooks which date from the first half of the twentieth century. ${ }^{1}$ With the notable exception of some eastern African contexts, these discussions may

\footnotetext{
${ }^{1}$ This study was funded by the Portuguese Fundação para a Ciência e Tecnologia (BPD/47681/2008), which I
} 
now support a peripheral footnote, generally obscured by harsh criticisms associating anthropological practice with various colonial projects, or replaced by the contemporary prevalence of urban settings. This article, however, focuses on an African/Saharan pastoral context: the arabophone population of Mauritania. ${ }^{2}$

The particular social landscape that I will endeavour to explore here is centred on a group of camel experts (shepherds, jockeys and camel trainers) who, in the late twentieth and early twenty-first centuries, migrated to the United Arab Emirates, where they encountered a surprising economic bonanza. ${ }^{3}$ This group is known in Mauritania by the term $z n \bar{a} g a$, a designation meaning 'white tributaries' specialised in livestock production, which places them at the lower end of the vertical statutory programme known to permeate the Saharan arabophone society (Baroja 2008 [1955]: 3-58; Bonte 1990; Hamès 1968; Lériche 1955; Marty 1919; Norris 1986; Ould Cheikh 1985; Rebstock 2011; Stewart 1973). This group will constitute the key object of this article, which will centre on the local readings triggered by their return to the Sahara during the first decade of the twenty-first century. Close attention will also be paid to the Ūlād Bāba Ahmad, a qabìla ('tribe', pl. qabā 'il) with a prominent role in this migratory process.

would like to thank for its support. In Mauritania, my work was much facilitated by Elemin ould Mohamed Baba, Mohamed Hmayada, Yahya ould al-Bara, Mahmuden ould Hally and Mohamed ould Sidi, my friends.

${ }^{2}$ Speakers of Hassāniyya, the lingua franca in western Sahara. This group is formed by bị̂ān communities (etymologically the plural of 'white', and the name attributed to the populations of 'noble'/'free' status) and various groups of tributary status, with a clear emphasis on the hrāțīn population (of slave descent), which presently forms a demographic majority. I avoid using the term 'Moorish' ('maure', in French) that usually describes the whole of these populations in European languages, as it does not in fact exist in Hassāniyya and is of very recent (colonial) use in Mauritania.

${ }^{3}$ The exact number of pastoral agents involved in this itinerary is difficult to establish, but it was probably around 600-800 people, mostly associated with three qabā 'il: Ūlād Bāba Ahmad, Tagunānt and Machduf. 
My interest in this subject was sparked by the work I had previously carried out on the Ūlād Bāba Ahmad leadership (Freire 2009: 178-97), during which I repeatedly came across fulsome praise regarding the successful incorporation of the qabilla's znāga families which had recently returned from the Emirates (about fifty families, totalling approximately 200 people). These formal assertions provided a conciliatory view of the group's statutory contexts, signalling, at the same time, the possible overcoming of any restraints to social mobility. I - naively - hoped that I could finally treat a Saharan subject where social 'antiques' such as tribal organisation, kinship-centred relations, the fastidious segmentary literature (Kuper 1982) or genealogical narratives would be nothing more than forgotten details of mere historical significance. Finally, however, due largely to the pervasiveness of genealogically based stratified social structures, this preliminary thought was dismissed as inadequate in understanding the contemporary role played by the znāga population. In this sense, my argument also highlights the interest in an effectively integrated reading of globalised migration experiences, which, contrary to what has often been suggested (Ong \& Collier 2005; Werbner 1999), should closely relate to local identification much more than to the cosmopolitan levels of these transits, or the simplistic framing of globalisation as an eminently high-tech opening of social and financial flows.

After working in the region for more than a decade, I was surprised that it proved much more difficult to explore the treatment of the statutory question than other subjects I had previously probed in Mauritania (notably Islam and genealogical tradition). For the first time, I had the experience of doors being slammed in my face, my privileged informants being incapable of helping me in any way, telephone calls being abruptly terminated the moment I told people about my research interests. Challenging my previous understanding, these new elements denoted the profound tensions still felt over the statutory questions, underlining, at the same time, an academic urgency in exploring this subject. 
The effective use of the expression znāga, if seemingly 'neutralised' by its inclusion in the lines of an academic article, must not hide its particularly difficult use. In fact, the annotation of Caro Baroja in the early 1950s, stating that the word znāga is 'the most heinous insult' in the Sahara (Baroja 2008 [1955]: 139, my translation), still seems appropriate. During fieldwork I have thus privileged the use of expressions such as 'shepherd' or 'herdsman', and only very seldom did I integrate the expression znäga into my interviews, it being, nevertheless, implicit in the topic and for the interlocutors I chose to address, as well as through my recognised knowledge of the genealogy of the particular qabīla I was focusing upon.

The geographical identity of the south-western Saharan arabophone population is defined, above all, by its flexibility. This quality largely derives from their use, up to a few decades ago, of extensive nomadic routes. This fact comprehends, in a maximalist view, the area between Guelmim (in southern Morocco) and the Senegal River margins, to the west, and the area between the Atlantic Ocean and Timbuktu, to the east, as their territory. On the other hand, this socio-geographical area can be circumscribed to the political/colonial borders of the current Islamic Republic of Mauritania. If we consider, for example, the recent development of a Saharawi political structure and identity, or the permeability of the southern and eastern frontiers of Mauritania, the region's population seems to continue to be committed to territories of very imprecise boundaries. This mobility of Saharan populations should justify different contemporary regional migrations (Bensaâd 2008; Choplin 2008, 2012; Ciavolella 2008; De Bruijn \& Van Dijk 2003), and even a transcontinental extension to North America, Western Europe, Southern Africa or even China, where Saharan communities are already recognised.

This social and geographical porosity of the western Saharan region is the backdrop for the persistent addition of the prefix 'trans-' to the word Sahara. The misuse of this term 
has been recently discussed by McDougall \& Scheele (2012), who stress that this label has provided a description of the Sahara and its populations mainly as a 'crossing', resulting from an intense exchange of goods and Islamic knowledge (Austen 2010; Curtin 1984; Gast 1981; Lydon 2009; Marfaing \& Wippel 2004). ${ }^{4}$ As defended throughout this article, the understanding of an eminently Saharan social and cultural sphere is long overdue.

\section{SAHARAN MIGRANTS IN THE EMIRATES}

In the first few months of 1982, thirty Mauritanian shepherds travelled from Nouakchott to Abu Dhabi as part of a programme to recruit labour specialised in camel husbandry. Some years later it was agreed that their families would be allowed to join them, and in 1986 a new party of about 300 migrants (all of them directly or indirectly linked to pastoral activities) flew to the UAE. This group was hosted by the Emirates army and initially accommodated in a military camp. They were later relocated to the town of as-Samha ashSha'abiīa, which was specifically conceived to receive them and which would be the base for the Mauritanian expatriate community in the Emirates (Ould Ahmed Salem 2007: 34). On top of a USD 400 per month salary, these shepherds were offered free medical care, education and housing (with sanitation, electricity 'and even air conditioning', absolute novelties for most of them). Some years later, the number of Mauritanians in the UAE had risen to $4,000,{ }^{5}$ and Muhammadīn ūld Ahmadu (from the Ūlād Bāba Ahmad qabīla), who enjoyed a privileged relationship with Shaykh Zayid bin Sultan al-Nahaīan (founder of the

\footnotetext{
${ }^{4}$ This possibility is confirmed by the data presented by Ghislaine Lydon (2009) on the totality of the western Saharan region, despite the title that the author (a historian) gave to her work: On Trans-Saharan Trails: Islamic Law, Trade Networks, and Cross-Cultural Exchange in Nineteenth-Century Western Africa.

${ }^{5}$ The Mauritanian community in the Emirates comprised, at this stage, besides the group of shepherds, a large contingent of military and police personnel, and a group of approximately 100 'religious professionals': teachers, judges, imams and theologians (Ould Ahmed Salem 2007).
} 
modern United Arab Emirates, and its leader from 1971 until his death in 2004), had become the acknowledged leader of the znäga community. Today, however, fewer than a dozen Mauritanian shepherds remain in the Emirates, and all the men previously conscripted into the army and police force have also returned to Nouakchott. Following the death of Shaykh Zayid in November 2004, his heirs soon lost interest in camel production, and a swift return to the Sahara was arranged for these low-tech agents of the global migration processes.

As we know, an overwhelming part of the identity narratives and genealogical traditions of the western Saharan arabophone population reclaim an ancestral connection with the Arabian Peninsula, most of which results from bonds with Arab characters who were supposedly established in the Saharan confines some centuries ago (Norris 1962). Oddly enough, and here reversing this initial east-west transit, Mauritania's 'Bedouin' ('pastoral') credentials continued to be recognised in Arabia. When in the early 1980s Emirati officials decided to recruit workers in Mauritania, the country was seen by wealthy Arabs as a place where they could still experience some sort of a 'return to the wild', where they could spend time hunting or practicing falconry (Grégoire 2000). It was most probably as a result of this exoticised vision of the Sahara and its populations that Shaykh Zayid sponsored the arrival of Mauritanian shepherds in Abu Dhabi, whilst aiming at a 'cultural revival' of his country, essentially by valuing its 'traditional' camel culture (Khalaf 1999; Insoll 2007; Jung 1994). ${ }^{6}$

One of the protagonists of this migratory itinerary (someone who returned to Mauritania in 2007, after having worked in Abu Dhabi as a camel trainer for more than a

\footnotetext{
${ }^{6}$ The Islamic credentials of the Saharan shepherds (invariably complemented with a pilgrimage to Mecca during their stay in the Gulf) constituted, most probably, another important aspect for their inclusion in the UAE: they follow the Maliki dogma revered in the Emirates. For an understanding of the theological production in the south-western Sahara, see Krätli \& Lydon 2011; Lovejoy 2012; and, in Arabic, Ould al-Bara 2009.
} 
decade) is very clear when questioned about the relationship that his employers had with camels:

They are great Bedouin ['badu ata']. ${ }^{7}$ I think they are even better than the Mauritanians, but as they became rich they stopped working directly with the animals. I am sure that was the only reason why they called us there. (...) I just wanted to work, and ended up flying to the Emirates almost by chance. When I left I thought I would go into the army, it was only afterwards that I learned that I would be working with Shaykh Zayid's camels. For more than ten years I was there preparing the camels, and the kids who rode them, ${ }^{8}$ for racing (Ūld 'Umar 2012 int). ${ }^{9}$

The recruitment of Saharan shepherds, over a time span of almost two decades, was in fact promoted, according to all my interlocutors, by Shaykh Zayid's interest in traditional desert culture (Khalaf 1990: 90, 98), as currently highlighted in his biographies. ${ }^{10}$ Part of the

\footnotetext{
${ }^{7}$ See 'badw', in Coon et al. 1986.

${ }^{8}$ It is worth mentioning the presence of Mauritanian children (but also Pakistani, Sudanese and Bangladeshi) in the camel-racing activities developed in the UAE. The numbers are, again, difficult to confirm, but the existing references mention more than 1,000 children (aged 5 and 6 years old), involved in this practice (Aljazeera 2006, accessed 7 March 2013). This sensitive issue was finally settled in 2006, with the direct involvement of UNICEF, resulting in the payment of indemnities to the families of most of these children by the UAE authorities (UNICEF 2007, accessed 7 March 2013). In the Gulf, human camel riders were meanwhile replaced by robot jockeys (Nawata 2005).

${ }^{9}$ These activities were developed together with migrants of other nationalities, notably Pakistanis (Bourgey 1991). Nonetheless, the latter supposedly did not go out with the animals, and were 'exclusively in charge of their feeding. In fact, the Mauritanians were the ones who took the camels to the pastures and who prepared them for racing' (Ūld 'Abdrāhman 2012 int).

10 'When the young Zayed was growing up, there was not a single modern school anywhere along the coast. $\mathrm{He}$, like his fellows, received only a basic instruction in the principles of Islam from the local Islamic preacher, although an enthusiasm and a thirst for knowledge took him out into the desert with the Bedouin tribesmen, absorbing all he could about the way of life of the people, their traditional skills and their hard-won ability to
} 
aspiration that Shaykh Zayid had for his country, in a decisive period of its history, was centred on his 'civilisational' interest in reviving desert culture, and, for that purpose, he revitalised an ancient connection with the western Saharan confines.

However, I am here treating only the last few decades of the past century and the early years of the twenty-first century. Today, as fewer than a dozen Mauritanian shepherds still work in the Emirates, the country's most popular sporting activities are football, car racing and golf: 'some call camel racing, falconry, and boat racing heritage sports because they hearken back to Bedouin tradition' (Darraj \& Puller 2009: 84-5; see also Dresch \& Piscatori 2005). ${ }^{11}$

\section{A SAHARAN $Q A B \bar{L} L A$ AND THEIR ZNĀGA}

The study of the arabophone western Saharan population has concentrated, as we know, on the analysis of hierarchically structured social configurations. Nevertheless, although the groups positioned at the lower end of this structure have recently become a focus of

survive under the harsh climatic conditions. These early years not only taught Sheikh Zayed about his country, they also brought him into contact with the people (...) When the first geological survey teams from foreign oil companies arrived to carry out a preliminary surface survey of the trackless wastes of Abu Dhabi's deserts, it was Sheikh Zayed who was assigned the task of guiding them' (UAEU 2012, accessed 26 November 2012). In the same tone, a young Shaykh Zayid is also described in Wilfred Thesiger's famous Arabian Sands: 'I had been looking forward to meeting him, for he had a great reputation among the Bedu. They liked him for his easy informal ways and his friendliness, and they respected his force of character, his shrewdness, and his physical strength. They said admiringly, "Zayid is a Bedu. He knows about camels, can ride like one of us, can shoot, and knows how to fight"” (Thesiger 2007 [1959]: 268-9).

${ }^{11}$ With this Arabian diversion I simply wish to underline the bilateral complexities of a migratory process which cannot be associated solely with the search for work by some destitute Saharans, but also included the particular interest of some eminent UAE officials. Important work remains to be done concerning the authorised efforts behind the recruitment of Saharan migrants in the Emirates. 
academic attention (Fortier 2006; Klein 2009, 2011; Leroux 2004; Rossi 2009; Searing 2003 [1993]; Seesemann 2004; Villasante-De Beauvais \& Acloque 2000; Willis 1985), very few studies have centred on the znāga population treated in this article. Among the different reasons that might justify the academic lack of interest in this particular subject, one aspect seems to stand out: the ambiguity of the tributary framing of this population. The znāga are, to a large extent, responsible for the - fundamental - development of the region's herds, thus creating bonds of great proximity with the owners of these herds. These bonds are, in some cases, centuries old, and cut across a simple professional relationship to encompass, in many cases, a shared genealogical project. Another fundamental aspect, which has probably diverted attention from this population, has to do with the colour of their skin: they are 'white tributaries' (Hall 2011; El Hamel 2012), when most of the observers prioritise the much more numerous - region's black population of servile origin, the hrātīn (Bullard 2005; Lecocq 2005; Lovejoy 2000; McDougall 2010; Ould Ahmed Salem 2009; Villasante-De Beauvais \& Acloque 2000; Wright 2007).

But let us now centre on the qabila that played a pivotal role in the Saharan shepherds' migration to the Gulf. The Ūlād Bāba Ahmad, known in south-western Mauritania since the mid-seventeenth century, are today composed of about 3,800 individuals. Their traditional territory extends roughly from the northern outskirts of the town of Mederdra, in the south, to Boutilimit, in the north. Today, a large majority of the group is permanently settled, either in the four villages they founded in the late 1990s (located 100 kilometres to the east of the capital), or in Nouakchott. The Ūlād Bāba Ahmad are historically included in the Tachumcha tribal confederation, and are also a 'fraction' of the Ūlād Daimān qabīla (Marty 1919: 194-5). The informally acknowledged Berber ancestry of this group should trace their roots to the north of the African continent, but more consolidated historical records detect them in southern Mauritania only from the mid- 
seventeenth century onwards. During this fundamental period an Emirate was formed in the region (Curtin 1971; Ould Sa'ad 1989; Taylor 2002), and it was precisely with the first of the Trarza emirs (Ahmad bin Damān) that the Ūlād Bāba Ahmad tribal eponym (d. c. 1631, in Lériche \& Ould Hamidoun 1948: 485) came into prominence, consolidating a genealogy and a statutory identity which is, to the present day, recognised as a qabila (Norris 1969: 499; Freire 2013: 187-9; Hall 2011: 60). In consonance with the structuring of the tripartite model that followed (and that is presently recognised), the Ūlād Bāba Ahmad assumed the role of 'marabouts' (zwāya, 'religious officiants'). ${ }^{12}$

The verticalised structure of the qabila comprises, in its interior, populations of different tributary status (laḥma, m'allamīn, znāga or ḥrạținn). These groups are clearly part of the tribal structure, even if, in most cases, they have no actual genealogical link with the tribal ancestor, thus being generally - if euphemistically - described as 'clients' or 'allies' (tkhila). Even if these groups lack a noble ancestry, their integration and active participation in the qabila are not compromised. In fact, this capacity to incorporate 'foreign' families is often considered a decisive advantage, ${ }^{13}$ as a qabila's regional influence is often paralleled to the number of 'allies' it manages to 'recruit'. The Ūlād Bāba Ahmad confirm this structure. The direct descendants of Bāba Ahmad evidently constitute a group with privileged nobility opportunities, but there are other ways of successfully integrating the qabīla. According to the Ūlād Bāba Ahmad, there is only one fundamental prerequisite for the assimilation of 'foreign' families: adherence to the statutory model drawn from the tribal

\footnotetext{
${ }^{12}$ Zwāya and hassān groups epitomise bị̀̂an 'social order' (Stewart 1973), the first, associated with religious practice and teaching, the second, with an Arabic-speaking 'aristocracy' that retained political supremacy over the south-western Saharan region (Sanneh 1976).

${ }^{13}$ The depth of these different bonds has long been highlighted, by, among others, Ibn Khaldûn: 'Clients and allies belong to the same category. (...) [A] client(-master) relationship leads to close contact exactly, or approximately in the same way, as does common descent' (Khaldûn 1989: 98).
} 
eponym (Freire 2009: 196). It is largely in this sense that one must understand the presence of families of znāga status in the qabīla, and the subsequent role played by the Ülād Bāba Ahmad leadership in the processes that took many of the qabīla's znāga (probably amounting to 200 individuals) to the UAE in the late twentieth century.

Proving the depth of these interconnections, one should note that, from the first hour, the qabilla's leadership decided to take a privileged vantage point over the 'exodus' of its shepherds to the Gulf. Muhammad ūld Muhammad Lamīn, younger brother to the qabilla's leader, was among the first group to leave Mauritania in the early 1980s, thus articulating between the expatriate community and the tribal leadership. From Nouakchott, this leadership managed to coordinate the recruitment of new migrants, provided small loans and even suggested investments (mainly in property) for the remittances that came from the Emirates.

In the past, the Ūlād Bāba Ahmad, today mostly sedentary, formed an essentially transhumant community. The severe droughts that ravaged the Sahara in the late 1970s (Swift 1977; Toupet 1983; Vermeer 1981) have accelerated the expansion of sedentary communities, consolidating the exponential development of towns such as Kiffa, Nema and, notably, Nouakchott. From the distance of a few decades, it is now important to consider the changes this process may have promoted (Adriansen 2008; Azarya 1996; Boesen 2007; Bollig \& Schulte 1999; Chatty 2005; Gallais 1972; Salzman 2004).

If one focuses on how sedentarisation - incomplete and very recent - has been implemented, the complexity of the formulas currently generated is manifest. The sedentarisation of most of the Ūlād Bāba Ahmad has its clearest manifestation in the foundation (in the late 1990s) of the villages of Igerm, Awdach and Habibalash (86, 93 and 105 kilometres respectively from the Nouakchott-Boutilimit road), and Bir Jud (10 kilometres to the north of Mederdra), which were admittedly built from the proceeds of the 
migratory experience of their inhabitants. These communities chose to settle in the vicinity of the urban centres of Mederdra and Boutilimit, where some have also bought property, and where their children go to school (in fact, the urban and rural spheres suffer from profound demographic fluctuations which follow the school calendar). Nevertheless, the presence of znāga families in these towns (among which one must also include Nouakchott) combines with husbandry activities developed in the adjacent countryside, ${ }^{14}$ thus confirming an effective articulation between both spaces. ${ }^{15}$ Generally, the women and children travel during the weekends to the camps or small villages where the men live, or, conversely, the men rejoin their town-based families over the weekends (replicating, in this case, the pattern once practiced in the Emirates). During the 'wet season' (khriff), between the months of July and September, families usually reunite in the countryside, accompanying their herds for the very limited period of abundance in south-western Mauritania.

Another important aspect concerning the residential identity of these communities relates to the fact that these recently founded villages are established in an area still associated with the qabila's 'traditional territory'. Thus, if on the one hand the znāga communities seem to have attained a certain degree of autonomy, on the other hand they are still, in some way, respectful of a qabilla-based social project that continues to frame them. The founding of villages by families of znāga status - that are, nevertheless, I insist, established within the qabila's recognised territory, or, more rarely, on its outer edges seems to question the ties of these families with their 'masters', from whom they are today, in fact, financially independent. This evidence should prove that the relations between groups of znāga status and bị̣̂̄n 'masters' define degrees of association which clearly differ

\footnotetext{
${ }^{14}$ Even with the massive sedentarisation of the region's populations, livestock remains a fundamental aspect of Mauritania’s economy (see Turner \& Hiernaux 2008; Wabnitz 2007).

15 As recognised in many other African contexts: Choplin 2009; Fourchard et al. 2009; Fratkin et al. 1994; Geschiere \& Gugler 1998; Hahn 2010; Kaufmann 2009; Spittler 2008.
} 
from a simple tributary relationship (which Pierre Bonte coined as relations of 'hierarchical alliance' [1987: 61]). As stated above, the incorporation of znāga families into the qabīla fundamentally occurs through their adherence to the statutory model that conjures the tribe's identity. This initial acceptance of the qabila's ontological programme is followed by a diversity of permanently negotiated arrangements between groups of different status, different kinship strategies (Alber et al. 2010) or even a shared genealogy that can go back several centuries (Freire 2009: 178-97). These alliances seem, nevertheless, to have been decisively disputed when znăga families managed to buy property and to become the owners of significant herds. This process, epitomised in the founding of new villages, is undoubtedly associated with the migratory remittances that came from the Gulf.

\section{CAMELS AND ISLAM: THE MALLEABILITY OF STATUTORY CATEGORIES}

Theoretically, the description of a zwāya qabīla from south-western Mauritania (Trarza region) should illustrate a group dedicated to teaching, writing, da 'wa work or trade (which is not, in any way, excluded from the list of 'licit' activities for a group of religious status [Levtzion 1987]). Nevertheless, it is another particular aspect that defines the Ūlād Bāba Ahmad as a very original case: their peculiar expertise in camel husbandry (Camelus dromedarius; see Brauer 1993; Marvin 1955; Monod 1967). This feature, always used in the description of the qabila, distances itself from the zwāya 'paradigm', according to which religious status groups are excluded from raising camels and should dedicate themselves 'exclusively' to cattle husbandry. ${ }^{16}$

This important aspect has its origins in the mid-seventeenth-century consolidation of

\footnotetext{
16 'Comme tous les Arabes, les Maures font une distinction entre les "beggâra” [see Holt 1986: 962], gents des bœufs, et les "ebbâla", éleveurs de chameaux; et ils disent (...) "les chameaux ne sont pas le bien du marabout; ce qui est le bien du marabout, c'est les bovidés"' (Leriche \& Ould Hamidoun 1948: 526).
} 
the region's statutory roles, following the foundation of the Trarza emirate (Searing 2003: 90). After the In Titam battle (1630 or 1631), a Bani Hassān (Arab) leadership was established in the region, and the then defeated groups (from which the Ūlād Bāba Ahmad descend) were 'condemned' to remain solely in charge of cattle production. The - mainly ideological - association with camel culture was a right reserved to the tribes of Arab genealogy that had political control over the region, henceforth consolidating a separation between the zwāya and hassān (or 'arab) status. The irrefutable connection between the Ūlād Bāba Ahmad and camel-raising demonstrates a proximity with the emirate's leadership, who saw the camel as the privileged emblem of a noble 'ethic', portraying this group as the indomitable masters of the Sahara. Following this contextualisation, the Ūlād Bāba Ahmad are thus confronted with a serious statutory paradox. In fact, other inconsistencies with the 'traditional order' are to be found when we examine the current livestock production of the qabīla. The interest in cattle presently shown by the Ūlād Bāba Ahmad is justified by the geographical restriction of pastoral routes (which severely limits the success of camel-raising) following profound ecological (and residential) transformations. ${ }^{17}$ This contemporary shift in animal production could finally consolidate a rapprochement to the 'true' values of the $z w \bar{a} y a$ order. But, in reality, this point was never made by my interlocutors, who simply referred to the adoption of better suited and more profitable husbandry practices.

But let us now consider the trait that effectively establishes the identity of the Ūlād Bāba Ahmad as a zwāya qabīla: their religious dimension. Some of the most notable 'talents' of 'Bāba Ahmad al-Daymān̄̄', the tribe's eponym, are described in H. T. Norris's

\footnotetext{
${ }^{17}$ One type of process extensively studied in East African contexts: Casciarri 2009a; Degen et al. 2011; Galvin 2009; Lewis 1975; Österle 2008.
} 


\section{'Znaga Islam': ${ }^{18}$}

Saints such as Abā Zayd of the Īdaygub and his cousin Bāba Ahmad al-Daymānī, provided food or rain when either was scarce, punished offenders by long-distance guidance of meteors and magic spells, and undertook swift journeys on holy donkeys and on flying sticks (1969: 499).

The above quote illustrates some of the mystical dimensions that have often been recognised in the zwāya groups from south-western Mauritania. ${ }^{19}$ Based on these sources I questioned the leader of the qabila about the contemporary value of Bāba Ahmad's wellknown 'miracles' (see Hamès 2008: 92):

It is true that that dimension exists, but today people do not pay much attention to it. It might be important for other groups, but we do not pay importance to those aspects, and never provide those kinds of service! Even in the relationship we have with our $z n \bar{a} g a$, we never use those arguments. As we are strong, we do not need to do it! Ahmad ūld Muhammad Mahmūd [a previous leader of the qabìla], for example, did not even pray next to his znāga. He always tried to look strong next to them. As a matter of fact, if we show ourselves too 'maraboutique' [mrabit], the znāga won't respect us anymore (Ūld Muhammad Lamīn 2011 int). ${ }^{20}$

\footnotetext{
${ }^{18}$ This title does not relate to the $z n \bar{a} g a$ status studied in this article, but to the south-western Saharan groups of Berber ancestry, termed, like the language they spoke (Al-Chennafi 1981), by this same noun (see Hart 1997). ${ }^{19}$ The research carried out by this author in postcolonial Mauritania is fundamental for the access in European languages to the vast literary production of the western Saharan region. His focus on literary, musical and poetic traditions constitutes a fascinating piece of work, decisive in the consolidation of a corpus that illustrates the richness and diversity of Saharan literate traditions.

${ }^{20}$ One should also note that Daddah attended Boutilimit's (colonial) 'madrassa al-ūlād al-shiukh al-qabā 'il' ('madrassa of the sons of the tribal leaders') during the 1950s, confirming the interest that the French authorities had in controlling the region's traditional leaderships (Ben Hounet 2008; Lesourd 2009; Taylor 2007).
} 
This statement is significant as it conjugates the qabila's 'official' narrative concerning its exoteric dimensions and the tributary role ascribed to the znāga communities. ${ }^{21}$ To a large extent it is the actual zwāya status - as historically described that seems to be called into question. Today, an apparently 'deculturalised' structure appears to be gaining ground (Roy 2008: 196-7), thus framing the qabila's religious spheres at completely different levels from the ones that 'traditionally' described the group's eponym and many of its more distinguished descendants (Cleaveland 1998). This fundamental debate should be carried out in conjunction with a wider regional incorporation of Islamic readings that question the mystical dimensions which, until recently, largely defined Islamic practice in the western Sahara (Hamès 2008; Ould El-Bara 2007). ${ }^{22}$ The Ūlād Bāba Ahmad's adherence to a 'saner' Islam (that in its political version is usually classified as 'Islamist'; see Hill 2012; Hunwick 1997; Otayek 2011), still correlates, however, 'traditional' practices and the 'reformist' charters of contemporary Islamic theology. Even though the Ūlād Bāba Ahmad continue to be associated with their extraordinary mystical powers and their success in husbandry, these representations are currently being questioned and redefined, again

\footnotetext{
${ }^{21}$ Religious status groups were also recognised by their cruelty in the treatment of tributary populations, as noted by the French adventurer René Caillié at the beginning of the nineteenth century: 'De toutes les classes des Maures, les marabouts sont ceux qui donnent le moins et demandent le plus (...) Ils traitent leurs esclaves avec barbarie, ils ne leur donnent que des noms insultants, les frappent, exigent d'eux beaucoup de travail, ne leur fournissent que très peut de nourriture, et, pour tout vêtement, une peau de mouton' (Caillié 1996 [1830]: 142-4; see also Ensel 1999).

${ }^{22}$ If in the neighbouring Algerian context state-sponsored support of 'traditional' Islam was attempted in the 1990s (hoping to domesticate the militant Islamic trends; see Ahmad 2006), thus 'recycling' the 'popular' baraka (Scheele 2007: 313-4; see also Bava 2003; Brenner 2001; Rosander 1997; Soares 2005), in the case of the Ūlād Bāba Ahmad (which can easily be extended to other Mauritanian contexts) one might think it was something more likely to have caused the 'death of the baraka'.
} 
confirming the 'liquid' use of the Saharan statutory model, and the likely dilution of any definitive features associated with pre-established statutory orders.

\section{BACK TO THE SAHARA, AND TO THE $Q A B \bar{I} L A:$ SIGNIFICANT CONTINUITIES}

If the above-mentioned elements assert the need for new analytical subjects to be incorporated, as well as the vitality of the Mauritanian tribal structures, when one focuses on the statutory identity of the znāga families recently returned from the Gulf one is often faced with seemingly unchangeable formulas. The alterations that are noticeable, for example, in the models of animal husbandry, religious practice or spatial identity have not yet been felt at the more 'intimate' levels of tribal structure, particularly if we consider intra-tribal statutory mobility. If the extraordinary income earned abroad was enough for many znāga families to buy property, cars or animals (Haas 2006; Radeny et al. 2007), this was not sufficient to celebrate, for example, the marriage between a znāga man and a woman of noble/free status, even if she had considerably fewer financial resources. Notwithstanding various such attempts, such an alliance is still considered illicit. The impossibility of znāga men marrying women of higher status was, in fact, repeatedly referred to me as one of the most complex - and currently intractable - problems facing the qabila. ${ }^{23}$

If on the one hand the zwāya status of the qabila is, as we saw, open to change, its internal hierarchised programme seems, on the other hand, determined to keep its historically recognised form. There are only two ways to accomplish an effective change of status: either a new genealogical project is created (thus silencing another), and consolidated possibly over the course of a century, until the traces of a servile origin are lost, or a new statutory framework is created through a radical residential change, by getting away from the place of origin. Both options, in which we can identify different Saharan examples (but

\footnotetext{
23 Conversely, several cases are known of znāga women who married men of free/noble status.
} 
not among the Ūlād Bāba Ahmad), imply a clean break from any tribal bonds. In fact, the Saharan tribal model seems to lack the malleability to generate an endogenous mechanism capable of solving this most sensitive question.

But let us come back to the issue of the professional requalification of the Mauritanian shepherds who migrated to the UAE. In reality, their remarkable expertise remains a fundamental asset if we consider the choices they made after their return to the Sahara: most of them remain dedicated to raising livestock. A decisive transformation has nevertheless taken place, as now, contrary to what happened in the past, they own their own herds:

Today, most of them do not have the life they once had. We can find chauffeurs, guards, businessmen ... Many of them possess some livestock, but instead of tending the herds themselves, they leave them with relatives. All their children are now schooled, and they all know the Quran. Many of them have started to attend school in the Emirates. Their life has in fact improved a lot. It was, nevertheless, due to their capacity as shepherds that they achieved all this (Ūld Mahand Baba ūld Mazruf 2012 int).

Today I am guardien in a firm in Nouakchott. I have some animals, which I leave with relatives in the village [of Bir Jud, to the north of Mederdra]. Most of us have not gone back to the countryside. I even bought a plot of land, and built a house here in Nouakchott. If I had not gone to the Emirates, perhaps I would still be in the countryside. Today I have my own animals, and I no longer have to care for the livestock of others. My family, all of my brothers, who have not been in the Emirates, they all still live in the countryside (Ūld 'Umar 2012 int).

The association of the Ūlād Bāba Ahmad within eminently rural spheres should be conciliated with an association with urban contexts, from which they extract revenue adding to what they earn through husbandry. One could thus describe a diversified residential and professional structure that conjugates urban and rural life. Nevertheless, this structure does not hinder the pervasive influence of genealogically based narratives, and the possible statutory reconversion of the znāga populations. The 'official' statement that the Ūlād Bāba 
Ahmad's unchallenged 'traditional leader' (shaykh taqlidia) insisted on making regarding the role of the man who once led the znäga community in the Emirates - and who is presently a thriving cattle owner (Bonte 2000; Casciarri 2009b; Ould Ahmed Salem 2001) gives us a clear indication of the complexity of the processes here: 'Let me tell you this very clearly: he can represent us anywhere! He's a great, great man, and can represent us at all levels and in any place! Not only as a Ūlād Bāba Ahmad, but also as a Ūlād Daimān, or a Tachumcha!' (Nouakchott, 9 April 2012).

This statement might prove that a znāga origin does not constitute an impediment to the recognition of a 'shepherd' as the leading figure of the qabila, and that today this particular subject is authorised to politically participate fully in all tribal spheres. The importance that the 'traditional' leader now assigns to this agent can also be associated with his comfortable economic position, which might, for example, lead to a severe questioning of the traditional leadership of the qabila (Barth 1986 [1961]: 127). It should also be noted that it was precisely within the family circle of this 'distinct' znāga - a qabila's representative 'at all levels and in any place' - that some years ago a serious conflict broke out. And, by then, it was even suggested that all tribal bonds be definitively cut following another unsuccessful marriage due to the refusal of the bride's family (also from the Ūlād Bāba Ahmad) to accept a znāga as the husband to their daughter. ${ }^{24}$

\section{CONCLUSION}

Despite the recent academic interest in studies of globalisation and transnational flows, many of the materials presented in this article - if based on a transnational migration

\footnotetext{
${ }^{24}$ The depth of the genealogical stigma is even clearer in the case of the hrātīn population. The fundamental debate on this (majority) population continues to the present, with the renewed intervention of militant abolitionist groups that attempt to decisively question Saharan 'social order' (on this subject and its more recent developments, see Ould Ahmed Salem 2013).
} 
experience - resist an analysis exclusively focused on this perspective. The issues I have tried to address question the interpretation that consecrates the use of the pair 'cosmopolitism and globalisation' when, in fact, plenty of other concepts (such as history, nation, ethnicity and, in the case of the context dealt with here, social status) also play a significant role.

The processes discussed in this article support the opening of new research areas in the Saharan context, but they equally reiterate questions long explored in the region. The znāga example confirms that their passage through the Emirates has allowed only a limited degree of emancipation against the statutory bonds which, in many cases, still qualify these families as simple 'tributaries'. Even though their recently obtained earnings allow for decisive material improvements, as well as the guarantee of a qualified position in the political life of the tribe or the state, they still cannot accommodate the possibility of a marriage between a man of znāga status and a noble/free woman.

In Mauritania one can currently see ministers and even prime ministers who are known to be of tributary origin, and whose genealogy does not disqualify them as eminent statesmen. In these specific cases, in public service, or globally, in the labyrinths defining urban life, the traditionally hierarchised social order seems to have incorporated some degree of flexibility. However, as one attempts a detailed examination centred on qabilabased contexts and reflects, for example, on the adopted kinship strategies, one finds that the weight of genealogical narratives is still very present. My experience confirms an interest in continuing to discuss statutory roles in contemporary western Saharan contexts, and my reluctance to simply dismiss them as historically located regional curiosities. The examples studied here also prove that the present academic focus on the telling examples of slavery and slave descent are not at all comprehensive of the many forms of adherence to the western Saharan statutory model. Different forms of social mobility coincide in the efforts to 
question the limits established by the traditional statutory code or by kinship. Nevertheless, in the case of the znāga population, it is precisely these two interconnected elements (social status and genealogy) that seem to halt a - much desired - possibility of intra-tribal social mobility. This issue is, as we have seen, widely noticed, and furthermore identified by the tribal leaderships as the generator of profound tensions. Therefore, it is here argued that despite the recognised inefficiencies of the studies focusing, for example, on the 'segmentary' model, or on a 'totalising' qualification of kinship - that was once identified as 'the most fundamental organising principle of Arab society' (Rosenthal 1993: 967; see also Busby 1997; Conte and Walentowitz 2009) - such difficulties should not prevent the conduct of research in these particular fields, which continue to present themselves as decisive elements in the contemporary exploration of modern western Saharan social contexts. 


\section{Bibliography}

Adriansen, H.K. 2008. 'Understanding pastoral mobility: the case of Senegalese Fulani', The Geographical Journal 174, 3: 207-222.

Ahmad, I. 2006. 'Shades of Islamism: the state in Islamist thought”, ISIM Review 18: 12-13. Al-Chennafi , M. 1981. 'How the Hassāniyya vernacular of Mauritania supplanted Zenaga', Maghreb Review 6: 77-78.

Alber, E., T. Häberlein \& J. Martin. 2010. 'Changing webs of kinship: spotlights on west Africa", Africa Spectrum 3: 43-67.

Aljazeera. 2006.

http://www.aljazeera.com/news/middleeast/2006/12/2008525122821761480html, accessed 29.07.2013.

Austen, R.A. 2010. Trans-Saharan Africa in World History. New York, NY: Oxford University Press.

Azarya, V. 1996. 'Pastoralism and the state in Africa: marginality or incorporation?', Nomadic peoples 38: 11-36.

Baroja, J.C. 2008 (1955). Estudios saharianos. Madrid: Calamar.

Barth, F. 1986 (1961), Nomads of South Persia: the Basseri tribe of the Khamseh confederacy. Prospect Heights, IL: Waveland Press.

Bava, S. 2003. “"De la baraka aux affaires”: ethos économico-religieux et transnationalité chez les migrants Sénégalais mourides', Revue Européenne des Migrations Internationales, 19 (2): 69-84.

Ben Hounet, Y. 2008. 'Gérer la tribu ?', Cahiers d'Études Africaines, 191 : 487-512.

Boesen, E. 2007. 'Des localités nomades: les “maisons" Wodaabe en brousse et en ville', in Boesen, E. \& L. Marfaing, eds. Les nouveaux urbains dans l'espace Sahara-Sahel: un cosmopolitisme par le bas. Paris: Karthala; Berlin: ZMO, 209-231. 
Bollig, M. \& A. Schulte. 1999. 'Environmental change and pastoral perceptions: degradation and indigenous knowledge in two African pastoral communities', Human Ecology 27, 3: 493-514.

Bonte, P. 2009. 'Appartenances tribales et enjeux fonciers pastoraux en Mauritanie: le projet “Élevage II"”, Études Rurales 184: 149-168.

—. 2000. 'Faire fortune au Sahara: permanences et ruptures”, Autrepart 16: 49-65.

—. 1990. 'L'“ordre” de la tradition. Evolution des hiérarchies statutaires dans la société maure contemporaine', Revue du Monde Musulman et de la Méditerranée 54: 118-129.

—. 1987. 'Donneurs de femmes ou preneurs d'hommes ? Les Awlad Qaylan, tribu de l'Adrar Mauritanien', l'Homme 27, 102: 54-79.

Bourgey, A. 1991, 'Les Travailleurs Étrangers dans les Pays Arabes du Golfe', Revue du Monde Musulman et de la Méditerranée 62: 130-135.

Brauer, R.W. 1993. 'The camel and its role in shaping mideastern nomad societies', Comparative Civilizations Review 28: 106-151.

Brenner, L. 2001. Controlling knowledge: religion, power and schooling in a West African Muslim society. Bloomington, IN: Indiana University Press.

Bullard, A. 2005. 'From colonization to globalization: the vicissitudes of slavery in Mauritania', Cahiers d'études Africaines 45, 179/180: 751-769.

Busby, C. 1997. 'Of marriage and marriageability: gender and dravidian kinship', The Journal of the Royal Anthropological Institute 3, 1: 21-42.

Ciavolella, R. 2008. 'Fantasmer sur les hommes, tracer les frontières: l'histoire des frontières méridionales de Mauritanie', Studia Africana 19: 62-70.

Caillié, R., 1996 (1830). Voyage à Tombouctou. 2 vols. Paris: La Découverte.

Casciarri, B. 2009a, 'Between market logic and communal practices: pastoral nomad groups and globalization in contemporary Sudan (case studies from central and western Sudan)', 
Nomadic Peoples 13, 1: 69-91.

_. 2009b. 'Hommes, troupeaux et capital: le phénomène tribal au Soudan à l'heure de la globalization', Études Rurales 184: 47-64.

Casciarri, B. \& A.G.M. Ahmed 2009. 'Pastoralists under pressure in present-day Sudan: an introduction', Nomadic Peoples 13, 1: 10-22.

Chatty, D. ed. 2005. Nomadic Societies in the Middle East and North Africa: entering the 21st century. Leiden: Brill.

Choplin, A. 2008. 'L'immigré, le migrant, et l'allochtone: circulations migratoires et figures de l'étranger en Mauritanie', Politique africaine 109: 73-90.

- 2009. Nouakchott, au Carrefour de la Mauritanie et du Monde. Paris: Karthala.

- 2012. 'Mauritania and the new frontier of Europe: from transit to residence', in J.

McDougall, J. \& J. Scheele, eds. Saharan Frontiers: space and mobility in northwest Africa.

Bloomington, IN: Indiana University Press, 165-184.

Cleaveland, T. 1998. 'Islam and the construction of social identity in the nineteenth-century Sahara,' Journal of African History 39: 365-388.

Conte, E. \& S. Walentowitz. 2009. 'Kinship matters. Tribals, cousins, and citizens in southwest Asia and beyond', Études Rurales 184: 217-248.

Coon, C.S., H. von Wissmann, F. Kussamaul, \& W. Montgomery Watt. 1986. 'Badw', in H.A.R. Gibb, J.H. Kramers, E. Lévi-Provençal \& J. Schacht, eds. Encyclopedia of Islam, Volume 1. Leiden: Brill, 872-892.

Curtin, P.D. 1971. 'Jihad in West Africa: early phases and inter-relations in Mauritania and Senegal', The Journal of African History 12: 11-24.

- 1984. Cross-cultural Trade in World History. Cambridge: Cambridge University Press.

Darraj, S.M., \& M. Puller. 2009. United Arab Emirates. New York, NY: Chelsea House. 
De Bruijn, M., \& H.V. Dijk. 2003, 'Changing population mobility in West Africa: Fulbe pastoralists in Central and South Mali', African Affairs 102, 407: 285-307.

Degen, A. 2011. 'Transformation of Borana from nomadic pastoralists to agropastoralists and shift of livestock from cattle to include more goats, camels and sheep in Southern Ethiopia', International Journal of Business and Globalisation 6, 3-4: 292-312.

Dresch, P. \& J. Piscatori, eds. 2005. Monarchies and Nations: globalization and identity in the Arab states of the Gulf. London: I.B. Tauris.

El Hamel, C. 2012. Black Morocco: a history of slavery, race, and Islam. Cambridge: Cambridge University Press.

Ensel, R. 1999. Saints and Servants in Southern Morocco. Leiden: Brill.

Fortier, C. 2006. 'Intelligence pratique du berger et art magique du forgeron dans la société maure de Mauritanie', Cahiers d'Anthropologie Sociale, 1: 55-65.

Fourchard, L., O. Goerg \& M. Gomez-Perez, eds. 2009, Lieux de Sociabilité Urbaine en Afrique. Paris: Karthala.

Fratkin, E., K.A. Galvin \& E.A. Roth, eds. 1994, African Pastoralist Systems: an integrated approach. Boulder, CO: Lynne Rienner.

Freire, F. 2009. 'Narrativas naçrānī-s entre os bidān do sudoeste da Mauritânia: a viagem europeia e suas reconfigurações tribais. Lisboa, FCSH-UNL, tese de doutoramento em Antropologia.

- 2011. 'Histoire du Sahara atlantique et mémoire tribale. Réinterprétations contemporaines des contacts euro-sahariens précoloniaux', in S. Boulay \& B. Lecoquierre, eds. Le Littoral Mauritanien à l'Aube du XXIe Siècle. Paris: Karthala, 107-122.

—. 2013. 'Portugal (ainda) nos confins saarianos: definições contemporâneas do encontro pré-colonial no sudoeste da Mauritânia', M. C. da Silva, ed. Castelos a Bombordo. Etnografias de patrimónios africanos e memórias portuguesas. Lisbon, CRIA, 174-193. 
Gallais, J. 1972. 'Les sociétés pastorales ouest-africaines face au développement', Cahiers d'Études Africaines 12, 47: 353-68.

Galvin, K.A. 2009. 'Transitions: pastoralists living with change', Annual Review of Anthropology 38: 185-198.

Gast, M. 1981, 'Le désert saharien comme concept dynamique: cadre culturel et politique', Revue de l'Occident Musulman et de la Méditerranée, 32: 77-92.

Geschiere, P. \& J. Gugler. 1998. 'Introduction. The urban-rural connection: changing issues of belonging and identification', Africa 68, 3: 309-318.

Haas, H. de. 2006. 'Migration, remittances and regional development in southern Morocco', Geoforum: Journal of Physical, Human, and Regional Geosciences, 37: 565-580.

Hahn, H.P. 2010. 'Urban life-worlds in motion: in Africa and Beyond', Africa Spectrum, 3: 115-129.

Hall, B.S. 2011. A History of Race in Muslim West Africa, 1600-1960. New York: Cambridge University Press.

Hamès, C. 2008. 'Problématiques de la magie-sorcellerie en Islam et perspectives Africaines', Cahiers d'Études Africaines, XLVIII (1-2): 81-99.

Hart, D.M. 1997. 'Berber names and substrata in Mauritania and the Western Sahara: linguistic and ethno-historical guidelines for future research on a paradoxical problem', The Journal of North African Studies 2, 1: 58-71.

Hill, J. 2012. 'The cosmopolitan Sahara: building a global Islamic village in Mauritania', City \& Society 24, 1: 62-83.

Holt, P. M. 1986, 'Bakkāra”, in H. A. R. Gibb, J. H. Kramers, E. Lévi-Provençal \& J. Schacht, eds. Encyclopedia of Islam, Volume 1. Leiden: Brill, 962.

Hunwick, J. 1997, 'Sub-Saharan Africa and the wider world of Islam: historical and contemporary perspectives', in E.E. Rosander \& D. Westerlund, eds. African Islam and 
Islam in Africa: encounters between sufis and islamists. London: Hurst, 28-54.

Insoll, T. 2007. 'Changing identities in the Arabian Gulf: archaeology, religion, and ethnicity in context', in T. Insoll, ed. The Archaeology of Identities: a reader. Abingdon: Routledge, 308-325.

Jung, M. 1994. 'On representations of camels and camel-riders in the rock art of north Yemen', East and West 44, 2-4: 231-248.

Kaufmann, J.C. 2009. 'The sediment of nomadism', History in Africa 36: 235-265.

Khalaf, S. 1999. 'Camel racing in the Gulf. Notes on the evolution of a traditional cultural sport', Anthropos 94, 1-3: 85-106.

- 2000. 'Poetics and politics of newly invented traditions in the Gulf: camel racing in the United Arab Emirates', Ethnology 39, 3: 243-261.

_. 2010. 'Dubai camel market transnational workers: an ethnographic portrait', City \& Society 22, 1: 97-118.

Khaldûn, Ibn, 1989 (1967), The Muqaddimah: an Introduction to history. Princeton, NJ: Princeton University Press.

Klein, M.A. 2009. 'Slave descent and social status in Sahara and Sudan', in B. Rossi, ed. Reconfiguring Slavery: West African trajectories. Liverpool: Liverpool University Press, 2644.

2011. 'Slaves and soldiers in the western Soudan and French west Africa', Canadian Journal of African Studies 45, 3: 565-587.

Krätli, G. \& G. Lydon, eds. 2011. The Trans-Saharan Book Trade. Manuscript culture, arabic literacy and intellectual history in muslim Africa. Leiden: Brill.

Kuper, A. 1982. 'Lineage theory: a critical retrospect', Annual Review of Anthropology, 11: $71-95$.

Lecocq, B. 2005. 'The bellah question: slave emancipation, race, and social categories in 
late twentieth-century northern Mali', Canadian Journal of African Studies 39, 1: 42-68.

Lériche, A. 1955. 'Notes sur les classes sociales et sur quelques tribus de Mauritanie', Bulletin de l'IFAN XVII, 1-2: 173-203.

Lériche, A. \& M. Ould Hamidoun. 1948. 'Notes sur le Trârza: Essai de géographie historique', Bulletin de l'IFAN 10: 461-538.

Leroux, H. 2004. 'Le statut des serviteurs en tribus nomades, nécessaire évolution (cercle de Gao)', Mondes et Cultures 64, 1: 326-340.

Lesourd, C. 2009. 'Mauritanie: une école pour tous, une éducation pour qui?', in S. Caratini, ed. La question du pouvoir en Afrique du Nord et de l'Ouest. Volume 1. Paris: L'Harmattan, 153-182.

Levtzion, N. 1987. 'Merchants vs. scholars and clerics in West Africa: differential and complementary roles', in N. Levtzion \& H.J. Fisher, eds. Rural and Urban Islam in West Africa. Boulder, CO: Lynne Rienner Publishers, 21-38.

Lewis, I.M. 1975. 'The dynamics of nomadism: prospects for sedentarization and social change', in T. Monod, ed. Pastoralism in Tropical Africa. London: Oxford University Press, 426-442.

Lovejoy, P.E. 2012. 'Islamic scholarship and understanding history in west Africa before 1800', in J. Rabasa, M. Sato, E. Tortarolo \& D. Woolf, eds. The Oxford History of Historical Writing, 1400-1800 (Volume 3). Oxford: Oxford University Press, 212-232.

— 2000 (1983). Transformations in Slavery: a history of slavery in Africa. Cambridge: Cambridge University Press.

Lydon, G. 2009. On Trans-Saharan Trails: islamic law, trade networks, and cross-cultural exchange in nineteenth-century Western Africa. Cambridge: Cambridge University Press.

Marfaing, L. \& S. Wippel, eds. 2004. Les Relations Transsahariennes à l'Époque Contemporaine: un espace en constante mutation. Paris: Karthala. 
Marty, P. 1919. L'Émirat des Trarzas. Paris: Éditions Ernest Leroux.

McDougall, E.A. 2010. 'The politics of slavery in Mauritania: rhetoric, reality and democratic discourse', The Maghreb Review 35, 3: 259-286.

McDougall, J. \& J. Scheele. 2012. 'Introduction: time and space in the Sahara', in J. McDougall \& J. Scheele, eds. Saharan Frontiers: space and mobility in Northwest Africa. Bloomington, IN: Indiana University Press, 1-21.

Monod, T. 1967. 'Notes sur le harnachement chamelier', Bulletin de l'IFAN 29: 234-274.

Nawata, H. 2005. 'Historical socio-economic relationships between the Rashāyda and the Beja in the Eastern Sudan: the production of racing camels and trade networks across the Red Sea', Senri Ethnological Studies 69: 187-213.

Norris, H.T. 1986. The Arab Conquest of Western Sahara: studies of the historical events, religious beliefs and social customs which made the remotest Sahara a part of the Arab world. Harlow: Longman; Beirut: Librarie du Liban.

- 1969. 'Znaga Islam during the Seventeenth and Eighteenth Centuries', Bulletin of the School of Oriental and African Studies 32: 496-526.

- 1962. 'Yemenis in the Western Sahara', The Journal of African History 3, 2: $317-$ 322.

Ong, A. \& S.J. Collier, eds. 2007 (2005). Global Assemblages: technology, politics, and ethics as anthropological problems. Malden, MA: Blackwell Publishing.

Österle, M. 2008. 'From cattle to goats: the transformation of east Pokot pastoralism in Kenya', Nomadic Peoples 12, 1: 81-91.

Otayek, R., ed. 2011. Dimensions Transnationales de l'Islam Africain et Mutations Contemporaines du Sahel. Bordeaux: LAM/CNRS.

Ould Ahmed Salem, Z. 1998. 'Sur la formation des élites politiques et la mobilité sociale en Mauritanie', Nomadic Peoples 2, 1/2: 253-276. 
- 2001. 'Tcheb-tchib et compagnie: lexique de la survie et figures de la réussite en Mauritanie', Politique Africaine 82: 78-100.

- 2007. 'Islam in Mauritania between political expansion and globalization: elites, institutions, knowledge, and networks', in B. F. Soares \& R. Otayek, eds. Islam and Muslim Politics in Africa. Basingstoke: Palgrave Macmillan, 27-46.

2009. 'Bare-foot activists: transformations in the Haratine movement in Mauritania', in S. Ellis \& I. van Kessel, eds. Movers and Shakers: social movements in Africa. Leiden: Brill, 156-177.

— 2013. Prêcher dans le Désert: islam politique et changement social en Mauritanie. Paris : Karthala.

Ould Cheikh, A.W. 1985. Nomadisme, Islam et pouvoir politique dans la société Maure précoloniale (XIes.-XIXes.): Essai sur quelques aspects du tribalisme, Tese de Doutoramento, Université de Paris V - René Descartes.

Ould al-Bara, Y. 2007. 'Morsures de serpent: thérapie et magie chez les Bidân de Mauritanie', in C. Hamès, ed. Coran et Talismans: textes et pratiques magiques en milieu musulman. Paris: Karthala, 175-208.

- 2009. al-Majmū' 'a al-Kubrā al-chāmila li-fatāuā ua-nauazil ua-ahkām ahl gharb ua-janūb gharb al-Sahrā, 12 volumes. Nouakchott, Mawlây al-Hasan.

Ould Sa'ad, M.M. 1989. 'Emirats et espace émiral maure: Le cas du Trarza aux XVIIIeXIX siècles', Revue du Monde Musulman et de la Méditerranée 54: 53-82.

Radeny, M., D. Nkedianye, P. Kristjanson \& M. Herrero 2007. 'Livelihood choices and returns among pastoralists: evidence from Southern Kenya', Nomadic Peoples 11, 2: 31-55. Rebstock, U. 2011. "West Africa (tenth twelfth/sixteenth eighteenth centuries)", in M. Fierro, ed. New Cambridge History of Islam, Volume 2. Cambridge: Cambridge University Press, 480-502. 
Rosander, E.E. 1997. 'Introduction: The Islamization of "Tradition" and "Modernity", in E.E. Rosander \& D. Westerlund, eds. African Islam and Islam in Africa: encounters between sufis and islamists. London: Hurst, 1-27.

Rosenthal, F. 1993. 'Nasab', in C. E. Bosworth, E. van Donzel, W. P. Heinrichs \& Ch. Pellat, eds. Encyclopedia of Islam (Volume 7). Leiden: Brill, 967-968.

Sahlins, PARENTESCO 2013.

Roy, O. 2008. La Sainte Ignorance: le temps de la religion sans culture. Paris: Seuil.

Salzman, P.C. 2004. Pastoralists: equality, hierarchy, and the state. Oxford: Westview Press. Sanneh, L. 1976. 'The origins of clericalism in West African Islam', The Journal of African history 17, 1: 49-72.

Scheele, J. 2007. 'Recycling baraka: knowledge, politics, and religion in contemporary Algeria', Comparative Studies in Society and History 49, 2: 304 -328.

Searing, J. 2003 (1993), West African Slavery and Atlantic commerce: the Senegal river valley, 1700-1860. Cambridge: Cambridge University Press.

Seesemann, R. 2004. 'The shurafa and the 'blacksmith': the role of the Idaw 'Ali of Mauritania in the career of the Senegalese Shaykh Ibrahim Niasse (1900-1975)', in S. Reese, ed. The Transmission of Learning in Islamic Africa. Leiden \& Boston: Brill, 72-98. APAGAR

Soares B.F. 2004. 'Muslim saints in the age of neoliberalism', in B. Weiss, ed. Producing African Futures: ritual and reproduction in the neoliberal age. Leiden \& Boston: Brill, 79105.

Spittler, G. 2008. 'Caravaneers, shopkeepers and consumers - the appropriation of goods among the Kel Ewey Tuareg in Niger', in H. P. Hahn ed. Consumption in Africa, Anthropological Approaches. Münster: Lit Verlag, 147-172.

Stewart, C. C. 1973. 'Political authority and social stratification in Mauritania', in E. Gellner 
\& C. Michaud eds. Arabs and Berbers. London: Duckworth, 375-393.

Stewart, C. 1973. Islam and Social Order in Mauritania: a case study from the nineteenth century. Oxford: Clarendon.

Swift, J. 1977. 'Sahelian pastoralists: underdevelopment, desertification, and famine', Annual Review of Anthropology 6: 457-478.

Taylor, R.M. 2002. 'L'émirat pré-colonial et l'histoire contemporaine en Mauritanie', Annuaire de l'Afrique du Nord (1999) 37: 53-69.

—. 2007. 'Les frontières coloniales et leur imposition dans la vallée du Fleuve Sénégal, 1855-1871. Bouleversements des hiérarchies politiques et statutaires', in M.V. Cervello ed. Colonisations et Héritages Actuels au Sahara et au Sahel, Volume 1. Paris: L'Harmattan, 439-456.

Thesiger, W. 2007 (1959). Arabian Sands. London: Penguin.

Toupet, C. 1983. 'L'eau et l'espace au Sahel: l'exemple de la Mauritanie', Revue de Géographie de Lyon 58: 277-285.

Triaud, J.-L. 1985. 'Les agents religieux islamiques en Afrique tropicale: réflexions autour d'un thème', Canadian Journal of African Studies 19, 2: 271-282.

UAEU. 2012. < http://faculty.uaeu.ac.ae/ eesa/History/zayed.html >, accessed 26.11.2012.

UNICEF. 2007. < www.unicef.org/infobycountry/mauritania_40103.html >, accessed 07.03.2013.

Wabnitz, H.-W. 2007. 'The code pastoral of the Islamic Republic of Mauritania, return to the sources - Revival of traditional nomads' rights to common property resources", Recht in Afrika 10:139-174.

Turner, M.D., \& P. Hiernaux. 2008. 'Changing access to labor, pastures, and knowledge: the extensification of grazing management in Suadano-Sahelian West Africa', Human ecology 36, 1: 59-80. 
Vermeer, D.E. 1981. 'Collision of climate, cattle, and culture in Mauritania during the 1970s', Geographical Review 71, 3: 281-297.

Villasante-De Beauvais, M. 1991. 'Hiérarchies statutaires et conflits fonciers dans l'Assaba contemporain (Mauritanie): rupture ou continuité?', Revue du Monde Musulman et de la Méditerranée, ?????59-60: 181-210.

- 2000. 'La puissance politique du nasab en Mauritane contemporaine: A propos du rôle d'intermédiation de l'élite dirigeante des Ahl Sîdi Mahmûd de l'Assabâ', in P. Bonte \& H. Clawdot-Hawad, eds. Elites du Monde Nomade, Tuareg, et Maure. Aix-en-Provence: Edisud, 225-249.

Villasante-De Beauvais, M. \& B. Acloque eds. 2000. Groupes Serviles au Sahara: approche comparative à partir du cas des arabophones de Mauritanie. Paris: CNRS.

Werbner, P. 1999. 'Global pathways: working class cosmopolitans and the creation of transnational ethnic worlds', Social Anthropology 7, 1: 17-35.

Wright, J. 2007. The Trans-Saharan Slave Trade. London \& New York: Routledge.

\section{Entrevistas}

Daddah ūld Muhammad Lamīn, Ūlād Bāba Ahmad's traditional leader, Nouakchott, 29.06.2011.

Bachir ūld 'Abdrāhman, shepherd (12 years in the UAE), Mederdra, 13.04.2012.

Ahmadu ūld Mahand Baba ūld Mazruf, the 'facilitator' who from Nouakchott helped the znāga community in the Emirates, Nouakchott, 09.04.2012.

Muhammadīn ūld 'Umar, shepherd (10 years in the UAE), Nouakchott, 10.04.2012/19.04.2012. 